Article

\title{
New Steroidal Saponins from the Rhizomes of Paris vietnamensis and Their Cytotoxicity
}

\author{
Yang Liu ${ }^{1,+}$, Minchang Wang ${ }^{2,3,{ }^{\dagger}}$, Ke Liu ${ }^{2,3}$, Pengcheng Qiu ${ }^{1}$, Shan Zhang ${ }^{1}$, Yunyang Lu ${ }^{1}$, \\ Na Tang ${ }^{1}$ and Haifeng Tang ${ }^{1, *}$ \\ 1 Institute of Materia Medica, School of Pharmacy, Fourth Military Medical University, Xi'an 710032, China; \\ so870823@163.com (Y.L.); qpc023@126.com (P.Q.); zhangshan9815@163.com (S.Z.); \\ luyunyanggq@163.com (Y.L.); donnao7@163.com (N.T.) \\ 2 State Key Laboratory of Fluorine \& Nitrogen Chemicals, Xi'an 710065, China; wmc204@163.com (M.W.); \\ happycoco5133@163.com (K.L.) \\ 3 Xi'an Modern Chemistry Research Institute, Xi'an 710065, China \\ * Correspondence: tanghaifeng71@163.com; Tel.: +86-298-477-4748 \\ + The authors contribute equally to this work.
}

Received: 18 February 2018; Accepted: 4 March 2018; Published: 6 March 2018

\begin{abstract}
Four new spirostanol saponins, named pavitnosides A-D (1-4), with six known steroidal saponins 5-10 were isolated from the rhizomes of Paris vietnamensis. Their chemical structures were determined based on extensive spectroscopic studies and chemical methods. The aglycones of pavitnoside $B$ and pavitnoside $C$ were not reported in previous work. The cytotoxicity of all saponins was evaluated against human glioblastoma U87MG and U251 cell lines. The new spirostanol saponin 1 displayed weak anti-proliferative activity against U87MG cell line and the known saponins 8 and $\mathbf{9}$ exhibited significant cytotoxicity against the two tumor cell lines, with $\mathrm{IC}_{50}$ values of 2.16 to $3.14 \mu \mathrm{M}$, but did not affect the growth of primary cultures of human astrocytes.
\end{abstract}

Keywords: Paris vietnamensis; steroidal saponins; spirostanol saponins; cytotoxicity

\section{Introduction}

The genus Paris (Liliaceae) has been used as a traditional Chinese medicine for a long time. In the Chinese Pharmacopoeia, Rhizoma Paridis, recorded as the rhizomes of Paris polyphylla var. yannanensis and Paris polyphylla var. Chinensis [1], are widely used as folk medicine for heat-clearing and detoxifying, relieving swelling and pain, sore throat, snake bites and traumatic injure [2]. By extensive phytochemical and pharmacological studies, steroidal saponins have proven to be the chief active ingredients. Their significant bioactivities, including antitumor, anti-inflammatory, anti-melanogenic, antifungal, antiulcerogenic and hemostatic, have been confirmed in recent years [3-11]. As perennial plants, the domestic production of Rhizoma Paridis is insufficient, thus demand exceeds supply [2]. P. vietnamensis was chosen to investigate its chemical characteristics, aimed to replace Rhizoma Paridis and alleviate resource pressure. P. vietnamensis is mainly distributed in Guangxi, Yunnan province, China and North Vietnam. Its ideal growing environment is evergreen broad-leaved forest under $2000 \mathrm{~m}$ above sea level [12]. Up to now, one new and ten known steroidal saponins have been identified from the rhizomes of $P$. vietnamensis, and several compounds exhibit cytotoxic bioactivities [13]. These results prompted to continue further investigation on $P$. vietnamensis to discover novel structures and bioactive saponins. This paper describes the isolation and structural identification of four new spirostanol saponins and six known saponins (Figure 1), as well as the exploration of their in vitro cytotoxic activities. 

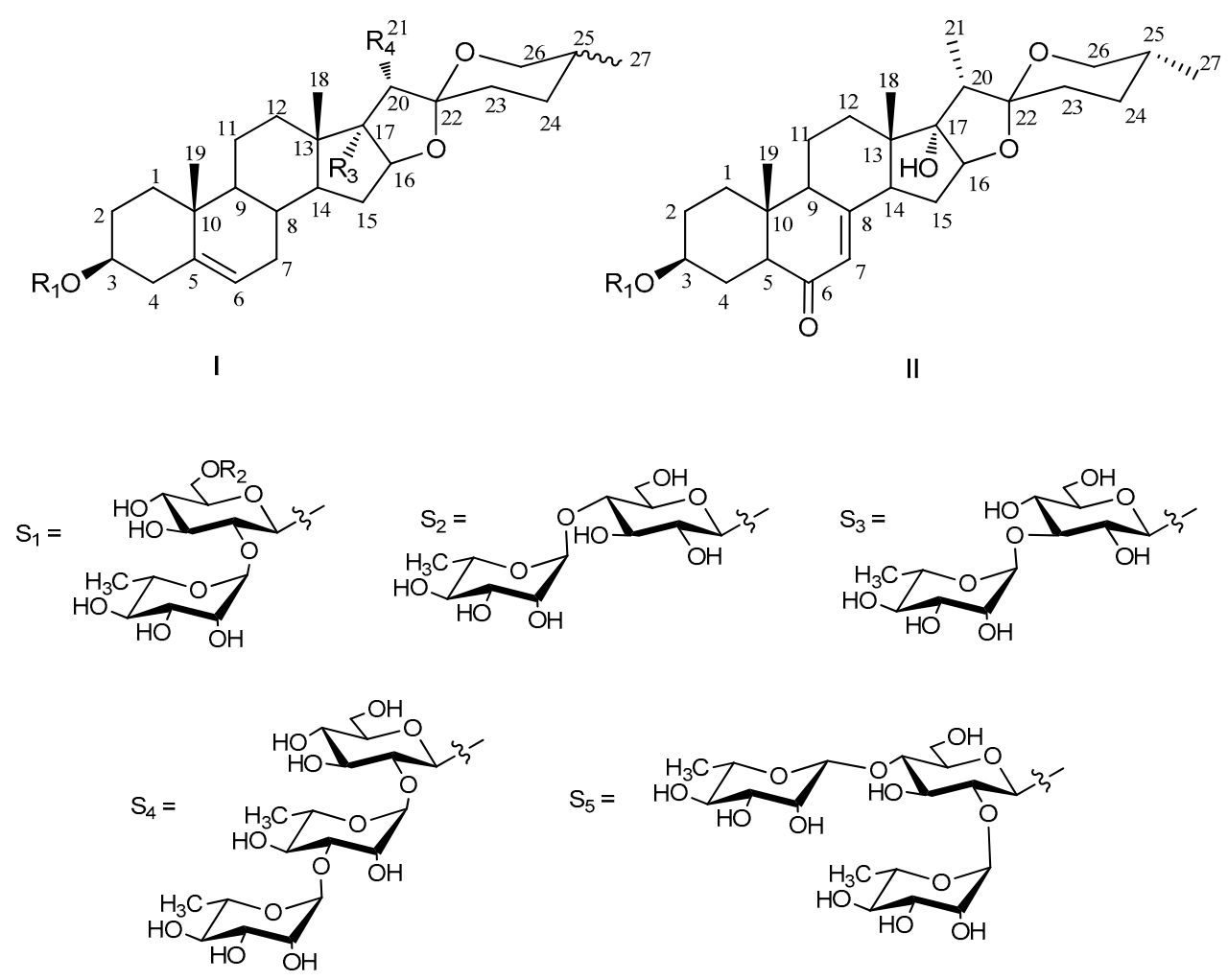

\begin{tabular}{ccccccc}
\hline & Aglycone & $\mathbf{R}_{\mathbf{1}}$ & $\mathbf{R}_{\mathbf{2}}$ & $\mathbf{R}_{\mathbf{3}}$ & $\mathbf{R}_{\mathbf{4}}$ & Configuration of C-25 \\
\hline $\mathbf{1}$ & $\mathrm{I}$ & $\mathrm{S}_{1}$ & $\mathrm{COCH}_{3}$ & $\mathrm{OH}$ & $\mathrm{CH}_{3}$ & $25 R$ \\
$\mathbf{2}$ & $\mathrm{I}$ & $\mathrm{S}_{1}$ & $\mathrm{H}$ & $\mathrm{OH}$ & $\mathrm{CH}_{2} \mathrm{OH}$ & $25 R$ \\
$\mathbf{3}$ & $\mathrm{II}$ & $\mathrm{S}_{1}$ & $\mathrm{H}$ & - & - & $25 R$ \\
$\mathbf{4}$ & $\mathrm{II}$ & $\mathrm{S}_{2}$ & $\mathrm{H}$ & - & - & $25 R$ \\
$\mathbf{5}$ & $\mathrm{I}$ & $\mathrm{S}_{1}$ & $\mathrm{H}$ & $\mathrm{OH}$ & $\mathrm{CH}_{3}$ & $25 R$ \\
$\mathbf{6}$ & $\mathrm{I}$ & $\mathrm{S}_{1}$ & $\mathrm{H}$ & $\mathrm{OH}$ & $\mathrm{CH}_{3}$ & $25 \mathrm{~S}$ \\
$\mathbf{7}$ & $\mathrm{I}$ & $\mathrm{S}_{3}$ & $\mathrm{H}$ & $\mathrm{OH}$ & $\mathrm{CH}_{3}$ & $25 R$ \\
$\mathbf{8}$ & $\mathrm{I}$ & $\mathrm{S}_{4}$ & $\mathrm{H}$ & $\mathrm{H}$ & $\mathrm{CH}_{3}$ & $25 R$ \\
$\mathbf{9}$ & $\mathrm{I}$ & $\mathrm{S}_{5}$ & $\mathrm{H}$ & $\mathrm{OH}$ & $\mathrm{CH}_{3}$ & $25 R$ \\
$\mathbf{1 0}$ & $\mathrm{I}$ & $\mathrm{S}_{1}$ & $\mathrm{H}$ & $\mathrm{H}$ & $\mathrm{CH}_{3}$ & $25 R$ \\
\hline
\end{tabular}

Figure 1. Structures of Compounds 1-10 from Paris vietnamensis.

\section{Results and Discussion}

Pavitnoside A (1), yellowish amorphous solid, was positive to Liebermann-Burchard and Molisch chemical reactions. The HR-ESI-MS exhibited a pseudomolecular ion peak at $m / z 803.4170$ $[\mathrm{M}+\mathrm{Na}]^{+}$(calcd. for $\mathrm{C}_{41} \mathrm{H}_{64} \mathrm{O}_{14} \mathrm{Na}$, 803.4194), corresponding to the molecular formula of $\mathrm{C}_{41} \mathrm{H}_{64} \mathrm{O}_{14}$, corroborated by analysis of ${ }^{13} \mathrm{C}-\mathrm{NMR}$ and DEPT spectral data. The ${ }^{1} \mathrm{H}-\mathrm{NMR}$ spectrum of 1 showed four methyl groups at $\delta_{H} 0.84(3 \mathrm{H}, \mathrm{s}, \mathrm{H}-18), 1.05(3 \mathrm{H}, \mathrm{s}, \mathrm{H}-19), 0.80(3 \mathrm{H}, \mathrm{d}, J=6.4 \mathrm{~Hz}, \mathrm{H}-27)$ and $0.90(3 \mathrm{H}, \mathrm{d}, J=7.2 \mathrm{~Hz}, \mathrm{H}-21)$ as well as one olefinic methine proton at $\delta_{H} 5.40(1 \mathrm{H}, \mathrm{br} \mathrm{s}, \mathrm{H}-6)$, which suggested a steroidal skeleton [14,15]. Additionally, an oxymethylene proton $(2 \mathrm{H}, \mathrm{m}, \mathrm{H}-26)$ was observed at $\delta_{H} 3.34$ and 3.49. The ${ }^{13} \mathrm{C}-\mathrm{NMR}$ spectrum of $\mathbf{1}$ revealed four angular methyl signals at $\delta_{C} 17.67(\mathrm{C}-18), 19.98(\mathrm{C}-19), 9.26(\mathrm{C}-21)$ and $17.64(\mathrm{C}-27)$, one trisubstituted double bonds at $\delta_{C}$ 142.03 (C-5) and $122.80(\mathrm{C}-6)$. Moreover, one quaternary carbon at $\delta_{C} 110.10(\mathrm{C}-22)$ is a characteristic hemiacetal signal of the spirostanol aglycone [14]. In the HMBC spectrum, the cross peaks between H-4 $\left(\delta_{H} 2.30\right.$ and 2.45$)$ and C-5 $\left(\delta_{C} 142.03\right) / C-6\left(\delta_{C} 122.80\right)$, between H-19 $\left(\delta_{H} 1.05\right)$ and C-5 $\left(\delta_{C} 142.03\right)$ deduced that the double bond was located at C-5/C-6 (Figure 2). The $\alpha$ configuration of C-17 was deduced by the chemical shifts of $\delta_{C} 90.68(\mathrm{C}-16)$ and $91.45(\mathrm{C}-17)$ [16-18]. The $\beta$ configuration of $\mathrm{C}-3$ 
was deduced by NOESY spectrum that correlation between H-3 $\left(\delta_{H} 3.53\right)$ and H-9 $\left(\delta_{H} 0.95\right)$ indicated $\mathrm{H}-3$ in $\alpha$-orientation. The $25 R$ configuration was confirmed by the difference chemical shifts between $\mathrm{H}-26 \mathrm{a}$ and $\mathrm{H}-26 \mathrm{~b}(\Delta \mathrm{ab}=0.15<0.48)[19-21]$. Considering these data and the reported literature [22], the aglycone of Compound 1 was identified as 25(R)-spirost-5-en-3 $\beta, 17 \alpha$-diol.

The ${ }^{13} \mathrm{C}-\mathrm{NMR}$ spectrum exhibited 41 signals, of which 27 were assigned to the aglycone moiety and 14 to the saccaride moiety. Acid hydrolysis of Compound 1 yielded D-glucose (Glc) and L-rhamnose (Rha) in a ratio of 1:1 by comparing the retention times with the corresponding authentic samples. The ${ }^{1} \mathrm{H}-\mathrm{NMR}$ spectrum of 1 showed two anomeric proton signals at $\delta_{H} 4.51(\mathrm{~d}, J=7.76 \mathrm{~Hz}, \mathrm{H}-1$ of Glc) and $\delta_{H} 5.20$ (br s, H-1 of Rha). Correspondingly, the correlations in HSQC of anomeric carbon signals were revealed at $\delta_{C} 101.04$ and $\delta_{C}$ 102.33, respectively. The sequence of all proton signals in monosaccharide was identified by combined use of ${ }^{1} \mathrm{H}-{ }^{1} \mathrm{H}$ COSY and TOCSY spectra. Then, the relative carbon signals were delineated through HSQC experiments (Table 1). In additional, one keto- methyl and one carbonyl carbon signals were observed at $\delta_{C} 20.89\left(3 \mathrm{H}, \mathrm{s}, \delta_{H} 2.05\right)$ and 172.89. The up-field shifts of the keto-methyl $\left(\delta_{H} 2.05\right)$ and Glc H-6 $\left(\delta_{H} 4.20\right.$ and 4.35$)$ implied that they may link the carbonyl group $\left(\delta_{C}\right.$ 172.89). In HMBC spectrum, the hypothesis was authenticated with long-rang correlations from $\mathrm{H}$ of keto-methyl $\left(\delta_{H} 2.05\right) /$ Glc H-6 $\left(\delta_{H} 4.20\right.$ and 4.35$)$ to C-carbonyl $\left(\delta_{C} 172.89\right)$. Moreover, the sequence of a disaccharide chain was confirmed by the cross peaks between Rha H-1 $\left(\delta_{H} 5.20\right)$ and Glc C-2 $\left(\delta_{C} 79.07\right)$ and the correlation from Glc H-1 $\left(\delta_{H} 4.51\right)$ to C-3 $\left(\delta_{C} 80.09\right)$ demonstrated the location of sugar linkage. This conclusion was supported by the NOESY spectrum exhibited in Figure 2. The $\beta$ configurations of D-glucopyranosyl was deduced by anomeric proton coupling constants $(J=7.6 \mathrm{~Hz}>7.0 \mathrm{~Hz})$, the $\alpha$ anomeric configuration of L-rhamnopyranosyl was confirmed by the chemical shifts of Rha C-5 at $\delta_{C} 69.91[23,24]$. Thus, the structure of Compound 1 was elucidated as 25(R)-spirost-5-en-3 $\beta, 17 \alpha$-diol-3-O- $\alpha$-L-rhamnopyranosyl-( $1 \rightarrow 2)$-6-acetyl- $\beta$-D-glucopyranoside, named Pavitnoside A (1).

Table 1. ${ }^{1} \mathrm{H}$ - and ${ }^{13} \mathrm{C}-\mathrm{NMR}$ data for Compounds $1-4$ in $\mathrm{CD}_{3} \mathrm{OD}^{\dagger}$.

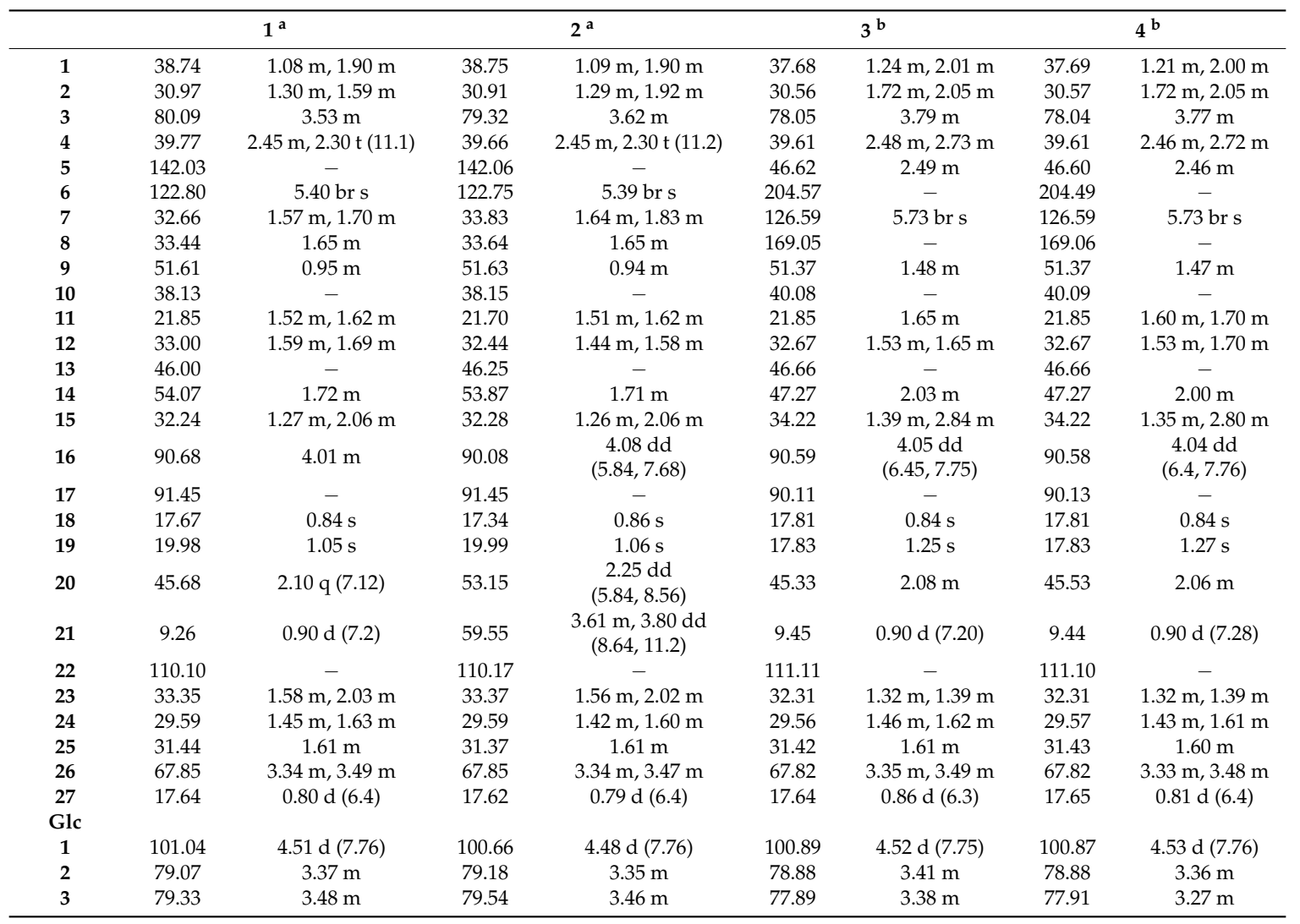


Table 1. Cont.

\begin{tabular}{|c|c|c|c|c|c|c|c|c|}
\hline & \multicolumn{2}{|c|}{$1^{a}$} & \multicolumn{2}{|r|}{$2^{a}$} & \multicolumn{2}{|r|}{$3^{b}$} & \multicolumn{2}{|r|}{$4^{b}$} \\
\hline 5 & 71.98 & $3.27 \mathrm{~m}$ & 71.99 & $3.26 \mathrm{~m}$ & 71.94 & $3.49 \mathrm{~m}$ & 71.94 & $3.27 \mathrm{~m}$ \\
\hline \multicolumn{9}{|c|}{$-\mathrm{COCH}_{3}$} \\
\hline 1 & 172.89 & - & & & & & & \\
\hline 1 & 102.33 & $5.20 \mathrm{br} \mathrm{s}$ & 102.33 & $5.19 \mathrm{br} \mathrm{s}$ & 102.16 & 5.22 br s & 102.18 & $5.21 \mathrm{br} \mathrm{s}$ \\
\hline 2 & 72.36 & $3.91 \mathrm{~m}$ & 72.38 & $3.91 \mathrm{~m}$ & 72.30 & $3.92 \mathrm{~m}$ & 72.31 & $3.92 \mathrm{~m}$ \\
\hline 3 & 72.52 & $3.66 \mathrm{~m}$ & 72.53 & $3.66 \mathrm{~m}$ & 72.51 & $3.66 \mathrm{~m}$ & 72.51 & $3.65 \mathrm{~m}$ \\
\hline 4 & 74.09 & $3.40 \mathrm{~m}$ & 74.09 & $3.39 \mathrm{~m}$ & 74.07 & $3.40 \mathrm{~m}$ & 74.06 & $3.38 \mathrm{~m}$ \\
\hline 5 & 69.91 & $\begin{array}{c}4.12 \mathrm{dd} \\
(6.24,9.60)\end{array}$ & 69.90 & $\begin{array}{c}4.14 \mathrm{dd} \\
(6.24,9.60)\end{array}$ & 69.85 & $\begin{array}{c}4.12 \mathrm{dd} \\
(6.25,9.50)\end{array}$ & 69.86 & $\begin{array}{c}4.12 \mathrm{dd} \\
(6.24,9.60)\end{array}$ \\
\hline
\end{tabular}

${ }^{\dagger}$ Assignments aided by the DEPT, ${ }^{1} \mathrm{H}^{1}{ }^{1} \mathrm{H}$ COSY, HSQC, HMBC, TOCSY, and NOESY experiments; ${ }^{\text {a }}$ tested at $800 \mathrm{~Hz},{ }^{\mathrm{b}}$ tested at $500 \mathrm{~Hz}$.

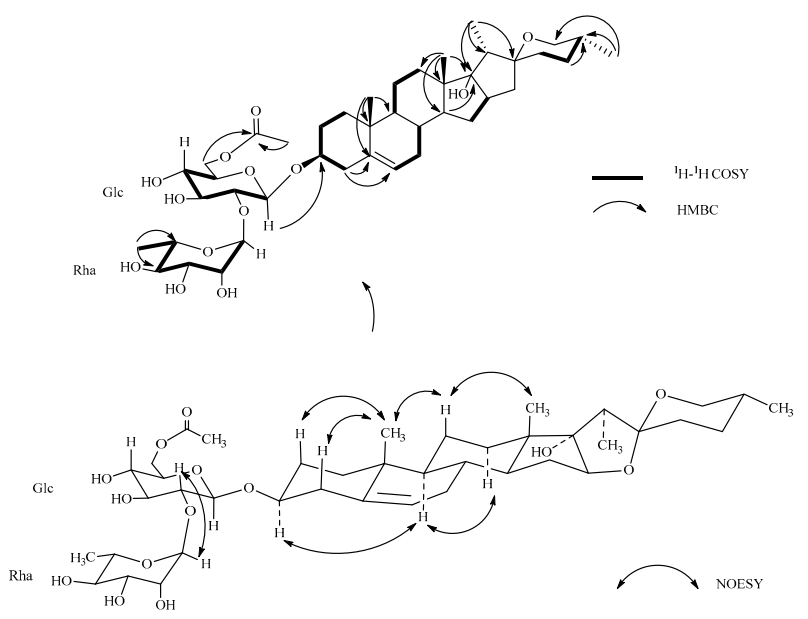

Figure 2. Key ${ }^{1} \mathrm{H}^{-}{ }^{1} \mathrm{H}$ COSY, HMBC and NOESY correlations of Compound $\mathbf{1 .}$

Pavitnoside B (2), white amorphous solid, was positive to Liebermann-Burchard and Molisch chemical reactions. The HR-ESI-MS showed a pseudomolecular ion peak at $m / z 777.4044$ [M $+\mathrm{Na}^{+}$ (calcd. for $\mathrm{C}_{39} \mathrm{H}_{62} \mathrm{O}_{14} \mathrm{Na}$, 777.4037), corresponding to the molecular formula of $\mathrm{C}_{39} \mathrm{H}_{62} \mathrm{O}_{14}$, corroborated by analysis of ${ }^{13} \mathrm{C}-\mathrm{NMR}$ and DEPT spectral data. In ${ }^{1} \mathrm{H}-\mathrm{NMR}$ spectrum of 2, three methyl signals were observed at $\delta_{H} 0.86(3 \mathrm{H}, \mathrm{s}, \mathrm{H}-18), 1.06(3 \mathrm{H}, \mathrm{s}, \mathrm{H}-19)$ and $0.79(3 \mathrm{H}, \mathrm{d}, J=6.4 \mathrm{~Hz}, \mathrm{H}-27)$ as well as one olefinic methine proton at $\delta_{H} 5.39(1 \mathrm{H}, \mathrm{br} \mathrm{s}, \mathrm{H}-6)$. The ${ }^{13} \mathrm{C}-\mathrm{NMR}$ spectrum of 2 exhibited corresponding carbon signals at $\delta_{\mathrm{C}} 17.34(\mathrm{C}-18), 19.99$ (C-19) and 17.62 (C-27), one trisubstituted double bonds at $\delta_{\mathrm{C}}$ 142.06 (C-5) and 122.75 (C-6). Compared to 1, one angular methyl at $\delta_{C} 9.26$ (C-21) was absent and the chemical shift of $C-20\left(\delta_{C} 53.15\right)$ was up-field $\left(\Delta \delta_{C}+7.47 \mathrm{ppm}\right)$, which indicated that a hydroxyl group substituted at the $\mathrm{C}-21$ primary carbon atom. It was evidenced by ${ }^{1} \mathrm{H}^{-}{ }^{1} \mathrm{H}$ COSY correlations between $\mathrm{H}-20\left(\delta_{H} 2.25, \mathrm{dd}, J=5.84,8.56 \mathrm{~Hz}\right)$ and $\mathrm{H}-21\left[\delta_{H} 3.61(\mathrm{~m}), 3.80(\mathrm{~m})\right]$ and by HMBC cross-peaks between $\mathrm{H}-21\left(\delta_{H} 3.61,3.80\right)$ and $\mathrm{C}-20\left(\delta_{C} 53.15\right) / \mathrm{C}-22\left(\delta_{C} 110.17\right)$, between $\mathrm{H}-20\left(\delta_{H} 2.25\right)$ and C-13 $\left(\delta_{C} 46.25\right) / C-21\left(\delta_{C} 59.55\right) / C-17\left(\delta_{C} 91.45\right) / C-22\left(\delta_{C} 110.17\right)$ (Figure S2). The double bond located at C-5/C-6 also confirmed by HMBC correlations between H-19 $\left(\delta_{H} 1.06\right)$ and C-5 $\left(\delta_{C} 142.06\right)$, between H-6 $\left(\delta_{H} 5.39\right)$ and C-4 $\left(\delta_{C} 39.66\right) / \mathrm{C}-7\left(\delta_{C} 33.83\right) / \mathrm{C}-10\left(\delta_{C} 38.15\right)$ (Figure S2). By comparison of $\mathbf{1}$, the configuration of $\mathrm{C}-17$ was $\alpha$-orientation and the $\beta$-configuration of $\mathrm{C}-3$ was also evidenced by NOESY spectrum. The chemical shifts between H-26a and H-26b $(\Delta \mathrm{ab}=0.13<0.48)$ decided the $25 R$ configuration [25]. Based on above evidence, the aglycone of Compound 2 was established as 
25(R)-spirost-5-en-3 $\beta, 17 \alpha, 21$-triol. The $C_{27}$ steroids aglycone of Compound 2 has not been reported in previous work.

GC analysis after acid hydrolysis of Compound $\mathbf{2}$ demonstrated the same monosaccharides as $\mathbf{1}$, i.e., presence of D-glucose and L-rhamnose. Compared to Compound 1, Compound $\mathbf{2}$ also obtained the same linkages of sugar moieties. The only difference was that the signals of 6 -acetyl connected with $\beta$-D-glucose were not observed in ${ }^{1} \mathrm{H}-\mathrm{NMR}$ and ${ }^{13} \mathrm{C}-\mathrm{NMR}$ spectrum. Thus, Compound 2 was characterized as $25(R)$-spirost-5-en-3 $\beta, 17 \alpha, 21$-triol-3-O- $\alpha$-L-rhamnopyranosyl-( $1 \rightarrow 2)-\beta$-D-glucopy ranoside, named Pavitnoside B (2).

Pavitnoside C (3), white amorphous solid, was positive to Liebermann-Burchard and Molisch chemical reactions. The molecular formula was established as $\mathrm{C}_{39} \mathrm{H}_{60} \mathrm{O}_{14}$ from the $[\mathrm{M}+\mathrm{Na}]^{+}$ion at $m / z 775.3884[\mathrm{M}+\mathrm{Na}]^{+}$(calcd. for $\mathrm{C}_{39} \mathrm{H}_{60} \mathrm{O}_{14} \mathrm{Na}, 775.3881$ ) in the HR-ESI-MS and the ${ }^{13} \mathrm{C}$ NMR spectral data. The ${ }^{1} \mathrm{H}-\mathrm{NMR}$ spectrum of 3 exhibited one olefinic methine proton at $\delta_{H} 5.73(1 \mathrm{H}, \mathrm{br} \mathrm{s}$, $\mathrm{H}-7)$. Four angular methyl signals at $\delta_{H} 0.84(3 \mathrm{H}, \mathrm{s}, \mathrm{H}-18), 1.25(3 \mathrm{H}, \mathrm{s}, \mathrm{H}-19), 0.90(3 \mathrm{H}, \mathrm{d}, J=7.2 \mathrm{~Hz}$, $\mathrm{H}-21)$ and $0.86(3 \mathrm{H}, \mathrm{d}, J=6.3 \mathrm{~Hz}, \mathrm{H}-27)$ implied that 3 also possessed a steroidal skeleton $[10,11]$. Correspondingly, one trisubstituted olefinic group at $\delta_{C} 126.59$ (C-7) and 169.05 (C-8) and four angular methyl signals at $\delta_{C} 17.81$ (C-18), 17.83 (C-19), 9.45 (C-21), 17.64 (C-27) were discovered in the ${ }^{13} \mathrm{C}-\mathrm{NMR}$. A characteristic quaternary carbon at $\delta_{C} 111.11(\mathrm{C}-22)$ was assigned in Compound 3 to a spirostanol aglycone. Compared to 1, C- 6 was displaced by a ketone carbon at $\delta_{\mathrm{C}} 204.57$, and the double bond changed to C-7/C-8. In HMBC spectrum, the cross peaks from $\delta_{H a} 2.48, \delta_{H b} 2.73(\mathrm{H}-4) / \delta_{H} 2.49(\mathrm{H}-5)$ to $\delta_{C} 204.57$ (C-6) confirmed the ketone location. The double bond $\Delta^{7(8)}$ was deduced by correlations between $\delta_{H} 5.73(\mathrm{H}-7)$ and $\delta_{C} 46.62(\mathrm{C}-5) / \delta_{C} 40.08(\mathrm{C}-10)$, between $\delta_{H} 2.03(\mathrm{H}-14) / \delta_{H} 1.25(\mathrm{H}-19)$ and $\delta_{C} 169.05$ (C-8) (Figure S3). According to the methodology, C-3, C-17 and C-25 possessed the same configuration with Compound $\mathbf{1}$. As a result, the aglycone of Compound 3 was determined as 25(R)-spirost-6-one-7-en-3 $\beta, 17 \alpha$-diol. The aglycone of Compound 3 has never been reported.

Acid hydrolysis of Compound 3 afforded D-glucose and L-rhamnose in accordance with the anomeric proton signals at $\delta_{H} 4.52(\mathrm{~d}, J=7.75 \mathrm{~Hz})$ and $\delta_{H} 5.22(\mathrm{br} \mathrm{s})$ as well as the anomeric carbon signals at $\delta_{C} 100.89$ and $\delta_{C}$ 102.16. Compared to 1 and 2, Compound 3 also obtained the sugar chain Rha- $(1 \rightarrow 4)$-Glc-, as was proven by HMBC spectrum (Figure S3). Thus, Compound 3 was elucidated as 25(R)-spirost-6-one-7-en-3 $\beta, 17 \alpha$-diol-3-O- $\alpha$-L-rhamnopyranosyl-( $1 \rightarrow 2)$ - $\beta$-D-glucopyranoside, named Pavitnoside C (3).

Pavitnoside D (4), white amorphous solid, was positive to Liebermann-Burchard and Molisch chemical reactions. The molecular formula was established as $\mathrm{C}_{39} \mathrm{H}_{60} \mathrm{O}_{14}$ from the $[\mathrm{M}+\mathrm{Na}]^{+}$ion at $m / z 775.3849[\mathrm{M}+\mathrm{Na}]^{+}$(calcd. for $\mathrm{C}_{39} \mathrm{H}_{60} \mathrm{O}_{14} \mathrm{Na}$, 775.3881) in the HR-ESI-MS and the ${ }^{13} \mathrm{C}-\mathrm{NMR}$ spectral data. Compared to 3, Compound 4 exactly possessed the same structure of aglycone and the monosaccharides experimented through acid hydrolysis. The main distinction was the sugar sequencing linkages depended on the correlation between $\delta_{H} 5.21$ (Rha H-1) and $\delta_{C} 79.43$ (Glc C-4). Thus, Compound 4 was established as $25(R)$-spirost-6-one-7-en-3 $\beta, 17 \alpha$-diol-3-O- $\alpha$-L-rhamnopyranosyl$(1 \rightarrow 4)$ - $\beta$-D-glucopyranosie, named Pavitnoside D (4).

The six known steroidal saponins 5-10 were determined as 25(R)-spirost-5-en-3 $\beta, 17 \alpha$-diol-3-O$\alpha$-L-rhamnopyranosyl-(1 $\rightarrow 2)$ - $\beta$-D-glucopyranoside (5) [26], 25(S)-spirost-5-en-3 $\beta, 17 \alpha$-diol-3-O- $\alpha$-Lrhamnopyranosyl-(1 $\rightarrow 2)$ - $\beta$-D-glucopyranoside (6) [27], 25(R)-spirost-5-en-3 $\beta, 17 \alpha$-diol-3-O- $\alpha$-L-rha mnopyranosyl-(1 $\rightarrow 3)$ - $\beta$-D-glucopyrano side (7) [28], 25(R)-diosgenin-3-O- $\alpha$-L-rhamnopyranosyl-(1 $\rightarrow 2$ )- $\alpha$-L-rhamnopyranosyl-( $1 \rightarrow 3)$ - $\beta$-D-glucopyranoside (8) [29], 25(R)-spirost-5-en-3 $\beta, 17 \alpha$-diol-3$O-\alpha$-L-rhamnopyranosyl-( $1 \rightarrow 4)$-[ $\alpha$-L-rhamnopyranosyl- $(1 \rightarrow 2)]-\beta$-D-glucopyranoside $(9)$ [30], and 25(R)diosgenin-3-O- $\alpha$-L-rhamnopyranosyl-(1 $\rightarrow 2)-\beta$-D-glucopyranoside (10) [31] by comparison of the physical and spectroscopic data (Supplementary Materials, Tables S1 and S2) with literature values.

Since steroidal saponins have been reported to possess varying cytotoxic activity against various cancer cell lines [32,33], human glioblastoma U87MG and U251 cells were selected to evaluate the cytotoxicities of the obtained spirostanol glycosides 1-10. The results of their cytotoxicities are shown in Table 2. Compounds $\mathbf{8}$ and $\mathbf{9}$ characterized at a branched trisaccharide chain attached to C-3 of 
the aglycone, exhibited significant cytotoxicities against the two test tumor cells, while saponin $\mathbf{1}$ displayed weak anti-proliferative activity on U87MG cell line. Saponins 2-7 and 10 possessing a disaccharide chain at C-3 of the aglycone displayed almost no activity $\left(\mathrm{IC}_{50}>100 \mu \mathrm{M}\right)$. It is worth noting that Compounds 1-10 did not affect the growth of primary cultures of human astrocytes. In fact, exposure of the astrocytes to the highest concentrations of 1-10 (100 $\mu \mathrm{M})$ for $72 \mathrm{~h}$ did not result in any statistically significant change in cell viability, with the inhibition ranging from $3.8 \%$ to $9.1 \%$ $(p>0.05)$. Meanwhile, the viability of astrocytes treated with $100 \mu \mathrm{M}$ ACNU for $72 \mathrm{~h}$ decreased to $67.4 \%(p<0.05)$. Comparing 1 with $2-7$, the acetyl group may influence the cytotoxic activity. On the other hand, it seemed that greater number of sugar residues at C-3 of the aglycone showed higher cytotoxic activity. However, the structure-activity relationship (SAR) for the antitumor activity of saponins involved the type of the aglycones; the type, number, sequence and binding sites of the sugar moieties; etc. [1]. For the limitation in the number of the isolated steroidal saponins, further studies on the cytotoxicity of the related saponins from P. vietnamensis are necessary to clarify their SAR.

Table 2. Cytotoxicities of saponins 1-10 against two human cancer cell lines and primary cultured astrocytes in vitro $\left(\mathrm{IC}_{50}, \mu \mathrm{M}\right)^{\mathrm{a}}$.

\begin{tabular}{cccc}
\hline \multirow{2}{*}{ Compounds } & \multirow{2}{*}{ Astrocytes } & \multicolumn{2}{c}{ Cell Lines } \\
\cline { 2 - 4 } & & U251 & U87MG \\
\hline $\mathbf{1}$ & $>100$ & $>100$ & $52.04 \pm 1.28$ \\
$\mathbf{2}$ & $>100$ & $>100$ & $>100$ \\
$\mathbf{3}$ & $>100$ & $>100$ & $>100$ \\
$\mathbf{4}$ & $>100$ & $>100$ & $>100$ \\
$\mathbf{5}$ & $>100$ & $>100$ & $>100$ \\
$\mathbf{6}$ & $>100$ & $>100$ & $>100$ \\
$\mathbf{7}$ & $>100$ & $>100$ & $>100$ \\
$\mathbf{8}$ & $>100$ & $2.16 \pm 0.65$ & $2.33 \pm 1.03$ \\
$\mathbf{9}$ & $>100$ & $3.14 \pm 1.26$ & $2.97 \pm 0.94$ \\
$\mathbf{1 0}$ & $>100$ & $>100$ & $>100$ \\
ACNU b & $>100$ & $0.96 \pm 0.05$ & $0.88 \pm 0.04$ \\
\hline
\end{tabular}

${ }^{a} \mathrm{IC}_{50}$ values are means from three independent experiments (average $\pm \mathrm{SD}$ ) in which each compound concentration was tested in three replicate wells; ${ }^{\mathrm{b}}$ Nimustine hydrochloride (ACNU) was the positive control.

\section{Experimental Section}

\subsection{General}

Optical rotations were measured on a Perkin-Elemr 241 MC digital polarimeter (German PerkinElmer Corporation, Boelingen, Germany). 1D and 2D-NMR spectral experiments were measured in $\mathrm{CD}_{3} \mathrm{OD}$ on a Bruker AVANCE-500 spectrometer (Bruker Corporation, Karlsruhe, Germany), with TMS as internal standard. IR spectra were recorded on a Shimadzu IRPrestige-21 spectrophotometer (Shimadzu Corporation, Tokyo, Japan). ESI-MS and HR-ESI-MS spectra were carried out on a Waters Quattro Micromass mass spectrometer (Waters, Shanghai, China). Column chromatographies (CC) were performed on silica gel H (10-40 $\mu \mathrm{m}$, Qingdao Marine Chemical Inc., Qingdao, China), ODS Silica gel (Lichroprep RP-18, 40-63 m, Merck Inc., Darmstadt, Germany) and Sephadex LH-20 (GE-Healthcare, Uppsala, Sweden). GC analysis was performed on an Agilent 6890N apparatus using an HP-5 capillary column $(30 \mathrm{~m} \times 0.32 \mathrm{~mm}, 0.25 \mu \mathrm{m})$ and an FID detector with an initial temperature of $120^{\circ} \mathrm{C}$ for $2 \mathrm{~min}$ and then temperature programming to $280{ }^{\circ} \mathrm{C}$ at the rate of $10^{\circ} \mathrm{C} / \mathrm{min}$. HPLC were carried out on a Dionex P680 liquid chromatograph equipped with a UV $170 \mathrm{UV} / \mathrm{Vis}$ detector at $206 \mathrm{~nm}$ and $225 \mathrm{~nm}$ using a YMC-Pack ODS-A column $(250 \times 20 \mathrm{~mm}$. D, S-5 $\mu \mathrm{m}, 12 \mathrm{~nm}, \mathrm{YMC}$, Kyoto, Japan) for semi-preparation. TLC detections were carried out on pre-coated plates with RP-18 (Merck) and silica GF254 (Qingdao Marine Chemical Inc., Qingdao, China) with 20\% $\mathrm{H}_{2} \mathrm{SO}_{4}$ followed by heating for three minutes. Standards for D-glucose (D-Glc) and L-rhamnose (L-Rha) were purchased from Sigma Chemical Co. (St. Louis, MO, USA). 


\subsection{Plant Material}

The dried rhizomes of Paris vietnamensis were collected from Ya'an, Sichuan Province, China in May 2016, and were identified by one of the authors, Haifeng Tang. The voucher sample (No. 20160520) was deposited in the Herbarium of Institute of Materia Medica, School of Pharmacy, Fourth Military Medical University, Xi'an, China.

\subsection{Extraction and Isolation}

The dried rhizomes of Paris vietnamensis $(2 \mathrm{~kg}$ ) were cut into pieces and refluxed with $70 \%$ ethanol $(10 \mathrm{~L})$ thrice (each $1.5 \mathrm{~h}$ ). The solution was merged and condensed with a vacuum rotary evaporator to receive a syrupy residue $(630 \mathrm{~g})$. The extraction was suspended in water $(3 \mathrm{~L})$ and successively extracted with petroleum ether and water saturated $n$ - $\mathrm{BuOH}$. The water saturated $n$-BuOH layer was evaporated under reduced pressure to afford an extraction (200 g). The crude extract was offered to silica gel column chromatography (CC) and eluted by gradient eluent of $\mathrm{CHCl}_{3}-\mathrm{MeOH}-\mathrm{H}_{2} \mathrm{O}(100: 1: 0$, 50:1:0, 20:1:0, 15:1:0, 8:1:0.1, 8:2:0.2, 7:2.5:0.25, 6.5:3.5:0.1, 6:3:0.3) to get 15 fractions (Fr.1-15) depending on the TLC results. Fr.9 (2.0 g) was eluted by $\mathrm{CHCl}_{3}-\mathrm{MeOH}(1: 1)$ on Sephadex LH-20 to get rid of pigmentum and then separated into two yields, Fr.9-1 (100 mg) and Fr.9-2 (600 mg), on ODS silica gel. Fr.9-2 was further isolated by semi-preparative HPLC using $\mathrm{MeCN}-\mathrm{H}_{2} \mathrm{O}$ (65:35) as the mobile phase at a flow rate of $6.0 \mathrm{~mL} / \mathrm{min}$ to afford Compounds $1\left(4.6 \mathrm{mg}, t_{R}=22.9 \mathrm{~min}\right), 2\left(3.2 \mathrm{mg}, t_{R}=15.9 \mathrm{~min}\right)$ and $5\left(2.4 \mathrm{mg}, t_{R}=13.5 \mathrm{~min}\right)$. Fr.11 (17.6 g) was eluted by MeOH on Sephadex LH-20 to get rid of pigmentum and was subjected to silica gel column chromatography (CC) and eluted by gradient eluent of $\mathrm{CHCl}_{3}-\mathrm{MeOH}-\mathrm{H}_{2} \mathrm{O}$ (10:1:0.1, 8:1:0.1, 6:3:0.3) to produce Fr.11-1 (9.2 g) and Fr.11-2 (500 mg). Fr.11-1 was further separated on ODS silica gel to give five fractions. Then, Fr.11-1-2 (86 mg) was isolated by semi-preparative HPLC using $\mathrm{MeCN}-\mathrm{H}_{2} \mathrm{O}$ (50:50) as the mobile phase at a flow rate of $8.0 \mathrm{~mL} / \mathrm{min}$ to afford Compounds $3\left(4.0 \mathrm{mg}, t_{R}=8.2 \mathrm{~min}\right), 6\left(83.4 \mathrm{mg}, t_{R}=16.7 \mathrm{~min}\right)$ and $7(3.3 \mathrm{mg}$, $t_{R}=32.9 \mathrm{~min}$ ). Fr.12 (24.0 g) was eluted by $\mathrm{CHCl}_{3}-\mathrm{MeOH}$ (1:1) on Sephadex LH-20 to get rid of pigmentum and was subjected to silica gel column chromatography (CC) and eluted by gradient eluent of $\mathrm{CHCl}_{3}-\mathrm{MeOH}-\mathrm{H}_{2} \mathrm{O}$ (20:1:0.1, 10:1:0, 8:2:0.2, 7:2.5:0.25) to produce three fractions. Fr.12-1 (1.2 g) was isolated by semi-preparative HPLC using $\mathrm{MeCN}-\mathrm{H}_{2} \mathrm{O}(80: 20)$ as the mobile phase at a flow rate of $8.0 \mathrm{~mL} / \mathrm{min}$ to afford Compounds $4\left(3.8 \mathrm{mg}, t_{R}=13.3 \mathrm{~min}\right)$ and 8 (5.4 mg, $\left.t_{R}=9.4 \mathrm{~min}\right)$. Fr.12-2 (4.2 g) was isolated by semi-preparative HPLC using $\mathrm{MeCN}-\mathrm{H}_{2} \mathrm{O}(70: 30)$ as the mobile phase at a flow rate of $8.0 \mathrm{~mL} / \mathrm{min}$ to afford Compound $9\left(16.8 \mathrm{mg}, t_{R}=19.5 \mathrm{~min}\right)$ and Compound $10\left(11.2 \mathrm{mg}, t_{R}=18.7 \mathrm{~min}\right)$. The purity of all compounds was assessed by HPLC as more than $95 \%$.

\subsection{Compound Characterization Data}

Pavitnoside A (1): Yellowish amorphous solid, $[\alpha]_{\mathrm{D}}^{22}-25.1$ (c 0.01, MeOH); IR (KBr) $v_{\max }\left(\mathrm{cm}^{-1}\right): 3422$,

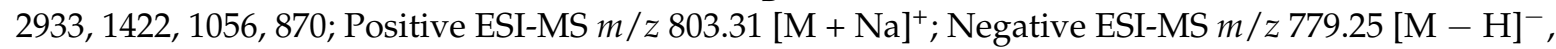
$737.26[\mathrm{M}-43]^{-}, 591.21[\mathrm{M}-146-43]^{-}$; Positive HR-ESI-MS $m / z$ 803.4170 [M + Na $]^{+} ;{ }^{1} \mathrm{H}-\mathrm{NMR}$ (800 MHz, CD 3 OD) and ${ }^{13} \mathrm{C}-\mathrm{NMR}(201 \mathrm{MHz}, \mathrm{CD} 3 \mathrm{OD})$ data, see Table 1.

Pavitnoside B (2): White amorphous solid, $[\alpha]_{\mathrm{D}}^{22}-49.2$ (c 0.05, MeOH); IR (KBr) $v_{\text {max }}\left(\mathrm{cm}^{-1}\right): 3420,2943$, 1661, 1070, 989, 892; Positive ESI-MS $m / z$ 777.47 [M + Na] $]^{+}$; Negative ESI-MS m/z 753.28 [M - H] $^{-}$, $737.29[\mathrm{M}-17]^{-}$; Positive HR-ESI-MS $m / z$ 777.4044 [M + Na] ${ }^{+} ;{ }^{1} \mathrm{H}-\mathrm{NMR}\left(800 \mathrm{MHz}, \mathrm{CD}_{3} \mathrm{OD}\right)$ and ${ }^{13} \mathrm{C}-\mathrm{NMR}\left(201 \mathrm{MHz}, \mathrm{CD}_{3} \mathrm{OD}\right)$ data, see Table 1.

Pavitnoside C (3): White amorphous solid, $[\alpha]_{\mathrm{D}}^{22}-92.2$ (c 0.06, MeOH); IR (KBr) $v_{\max }\left(\mathrm{cm}^{-1}\right): 3430,2920$, 1665, 1159, 1070, 989, 920, 900; Positive ESI-MS $m / z 775.43[\mathrm{M}+\mathrm{Na}]^{+}, 1527.94$ [2M + Na] $^{+}, 445.37[\mathrm{M}-$ $145-162]^{+}, 427.35[\mathrm{M}-146-162-17]^{+}, 409.35\left[\mathrm{M}-146-162-17-\mathrm{H}_{2} \mathrm{O}^{+}{ }^{+}\right.$; Positive HR-ESI-MS $m / z 775.3884[\mathrm{M}+\mathrm{Na}]^{+} ;{ }^{1} \mathrm{H}-\mathrm{NMR}\left(500 \mathrm{MHz}, \mathrm{CD}_{3} \mathrm{OD}\right)$ and ${ }^{13} \mathrm{C}-\mathrm{NMR}\left(125 \mathrm{MHz}, \mathrm{CD}_{3} \mathrm{OD}\right)$ data, see Table 1 . 
Pavitnoside D (4): White amorphous solid, $[\alpha]_{\mathrm{D}}^{22}-93.1(c 0.06, \mathrm{MeOH}) ; \mathrm{IR}(\mathrm{KBr}) v_{\max }\left(\mathrm{cm}^{-1}\right)$ : 3429, 2930, 1660, 1160, 1050, 989, 900; Positive HR-ESI-MS m/z 775.3849 [M + Na] ${ }^{+} ;{ }^{1} \mathrm{H}-\mathrm{NMR}$ (500 MHz, $\mathrm{CD}_{3} \mathrm{OD}$ ) and ${ }^{13} \mathrm{C}-\mathrm{NMR}\left(125 \mathrm{MHz}, \mathrm{CD}_{3} \mathrm{OD}\right)$ data, see Table 1.

\subsection{Acid Hydrolysis and GC Analysis of the Sugar Moieties in 1-4}

Compounds 1-4 (each $2 \mathrm{mg}$ ) were heated in an ampule with $2 \mathrm{~mol} / \mathrm{L} \mathrm{CF}_{3} \mathrm{COOH}(2 \mathrm{~mL})$ at $120{ }^{\circ} \mathrm{C}$ for $2 \mathrm{~h}$. The reaction mixture was extracted with $\mathrm{CHCl}_{3}(3 \times 5 \mathrm{~mL})$. The aqueous layer was concentrated in vacuo; $1 \mathrm{~mL}$ pyridine and $2 \mathrm{mg} \mathrm{NH} \mathrm{N}_{2} \mathrm{OH} \cdot \mathrm{HCl}$ were added to the dried residue; and the mixture was stirred at $90{ }^{\circ} \mathrm{C}$ for $1 \mathrm{~h}$. After the reaction mixtures were cooled, $1.5 \mathrm{~mL}$ of $\mathrm{Ac}_{2} \mathrm{O}$ was added and the mixtures were heated at $90^{\circ} \mathrm{C}$ for $1 \mathrm{~h}$. The reaction mixtures were concentrated under reduced pressure, and the resulting aldononitrile peracetates were analyzed by GC. The carbohydrates were determined by comparing the retention times with standard aldononitrile peracetates prepared from authentic sugars by the same procedure performed for the sample [1,34]. Retention times for authentic sugars after being derivatized were $5.61 \mathrm{~min}$ (L-Rha) and $11.56 \mathrm{~min}$ (D-Glc), respectively. L-Rha and D-Glc were identified in a ratio of 1:1 for Compounds 1-4.

\subsection{Cytotoxicity Assay for Compounds 1-10}

Human glioma cell lines U251 and U87MG were obtained from the Cell Bank of Chinese Academy of Science (Shanghai, China). Cultured primary astrocytes were obtained from a slightly impaired brain tissue fragment of a volunteer with cerebral trauma who consented to the procedure as described previously [35]. Acquisition of the tissue was approved by the local medical research ethics committee at Xijing Hospital, Fourth Military Medical University. The cell lines were cultured in DMEM (Corning, Beijing, China) supplemented with $10 \%$ FBS (Ausbian, Harbin, China) at $37^{\circ} \mathrm{C}$ with $5 \% \mathrm{CO}_{2}$. The logarithmic phase cells were seeded on 96-well plates at the concentration of 5000 cells/well and incubated with various concentrations $(100,10,1,0.1$, and $0.01 \mu \mathrm{M}$ in medium containing less than $0.1 \%$ DMSO) of Compounds 1-10 in triple wells for $72 \mathrm{~h}$. Nimustine hydrochloride (ACNU, Sigma, $\geq 99 \%$, Shanghai, China) was used as the positive control. Cell viability was determined according to reported assay methods using commercial CCK8 kit (7sea biotech, Shanghai, China) [36,37]. The optical density of each well was measured with a Bio-Rad 680 microplate reader at $450 \mathrm{~nm}$ (Bio-Rad Corporation, Hercules, CA, USA). Cytotoxicity was expressed as the concentration of drug inhibiting cell growth by $50 \%\left(\mathrm{IC}_{50}\right)$.

\subsection{Statistical Analysis}

All data are presented as the mean \pm standard deviation (SD) and analyzed using SPSS version 19.0 (SPSS Inc., Chicago, IL, USA). Unpaired test and one-way Analysis of Variance (ANOVA) followed by LSD test were performed for the differences between different groups. A value of $p<0.05$ was considered as statistically significant difference.

\section{Conclusions}

Phytochemical investigation of $P$. vietnamensis afforded 10 compounds, including four new compounds. The aglycones of Compounds $\mathbf{2}$ and $\mathbf{3}$ had never been isolated in the phytochemical studies and the ${ }^{1} \mathrm{H}-\mathrm{NMR}$ and ${ }^{13} \mathrm{C}-\mathrm{NMR}$ spectroscopic data were given for the first time in this study.

The experiments of cytotoxicity of all compounds showed that 8 and 9 exhibited notable cytotoxicity against the U87MG and U251 cell lines. However, Compounds 1-10 did not affect the growth of primary cultures of human astrocytes. It is suggested that saponins $\mathbf{8}$ and $\mathbf{9}$ are reliable candidates for chemotherapeutic treatment of human glioma.

Supplementary Materials: The physical and spectroscopic data of saponins 5-10, and NMR and MS spectra of saponins 1-4 are available online. 
Acknowledgments: The research work was financially supported by the National Natural Science Foundation of China (No. 81274029) and the Administration of Traditional Chinese Medicine of Shaanxi Province of China (No. 15-ZY024).

Author Contributions: H.T. conceived and designed the experiments; M.W. and K.L. collected the NMR data; Y.L. and N.T. contributed to the acid hydrolysis and GC analysis; P.Q. and S.Z. realized the evaluation of bioactivities; and Y.L. completed the isolation, elucidated the structural and wrote the paper.

Conflicts of Interest: The authors declare no conflict of interest.

\section{References}

1. Liu, Y.; Tian, X.; Hua, D.; Cheng, G.; Wang, K.; Zhang, L.; Tang, H.; Wang, M. New steroidal saponins from the rhizomes of Paris delavayi and their cytotoxicity. Fitoterapia 2016, 111, 130-137. [CrossRef] [PubMed]

2. Wen, F.Y.; Yin, H.X.; Chen, C.; Liu, X.B.; Xue, D.; Chen, T.Z.; He, J.; Zhang, H. Chemical characteristics of saponins from Paris fargesii var. brevipetala and cytotoxic activity of its main ingredient, paris saponin $\mathrm{H}$. Fitoterapia 2012, 83, 627-635. [CrossRef] [PubMed]

3. Watanabe, S.; Suzuki, T.; Hara, F.; Yasui, T.; Uga, N.; Naoe, A. Polyphyllin D, a steroidal saponin in Paris polyphylla, induces apoptosis and necroptosis cell death of neuroblastoma cells. Pediatric Surg. Int. 2017, 33, 713-719. [CrossRef] [PubMed]

4. Zheng, L.; Zheng, J.; Zhao, Y.; Wang, B.; Wu, L.; Liang, H. Three anti-tumor saponins from Albizia julibrissin. Bioorg. Med. Chem. Lett. 2006, 16, 2765-2768. [CrossRef] [PubMed]

5. Kawabata, T.; Cui, M.Y.; Hasegawa, T.; Takano, F.; Ohta, T. Anti-inflammatory and anti-melanogenic steroidal saponin glycosides from Fenugreek (Trigonella foenum-graecum L.) seeds. Planta Medica 2011, 77, 705-710. [CrossRef] [PubMed]

6. Deng, D.; Lauren, D.R.; Cooney, J.M.; Jensen, D.J.; Wurms, K.V.; Upritchard, J.E.; Cannon, R.D.; Wang, M.Z.; Li, M.Z. Antifungal saponins from Paris polyphylla Smith. Planta Medica 2008, 74, 1397-1402. [CrossRef] [PubMed]

7. Tian, Y.; Zheng, L.H.; Xu, Z.Y.; Sun, L.Q.; Gao, C.K.; Zheng, Q.Z.; Zhang, Z.H.; Shu, Y. Clinical and pharmacological study of the hemostatic action of Rhizoma Paridis by contraction of uterus. J. Tradit. Chin. Med. 1986, 6, 178-182. [PubMed]

8. Zaki, A.A.; Ali, Z.; Wang, Y.H.; El-Amier, Y.A.; Khan, S.I.; Khan, I.A. Cytotoxic steroidal saponins from Panicum turgidum Forssk. Steroids 2017, 125, 14-19. [CrossRef] [PubMed]

9. Jing, S.S.; Wang, Y.; Li, X.; Man, S.L.; Gao, W.Y. Chemical constituents and antitumor activity from Paris polyphylla Smith var. yunnanensis. Nat. Prod. Res. 2017, 31, 660-666. [CrossRef] [PubMed]

10. Yang, B.Y.; Bi, X.Y.; Liu, Y.; Li, G.Y.; Yin, X.; Kuang, H.X. Four New Glycosides from the Rhizoma of Anemarrhena asphodeloides. Molecules 2017, 22, 1995. [CrossRef] [PubMed]

11. Pereira, G.M.; Ribeiro, M.G.; da Silva, B.P.; Parente, J.P. Structural characterization of a new steroidal saponin from Agave angustifolia var. Marginata and a preliminary investigation of its in vivo antiulcerogenic activity and in vitro membrane permeability property. Bioorg. Med. Chem. Lett. 2017, 27, 4345-4349. [CrossRef] [PubMed]

12. Li, H. The Genus Paris (Trilliaceae); Science Press: Beijing, China, 1998; pp. 26-28.

13. Huang, Y.; Cui, L.J.; Wang, Q.; Ye, W.C. Separation and identification of active constituents of Paris vietnamensis. Acta Pharm. Sin. 2006, 40, 361-364.

14. Chen, P.Y.; Chen, C.H.; Kuo, C.C.; Lee, T.H.; Kuo, Y.H.; Lee, C.K. Cytotoxic steroidal saponins from Agave sisalana. Planta Medica 2011, 77, 929-933. [CrossRef] [PubMed]

15. Liu, H.; Chou, G.X.; Wang, J.M.; Ji, L.L.; Wang, Z.T. Steroidal saponins from the rhizomes of Dioscorea bulbifera and their cytotoxic activity. Planta Medica 2011, 77, 845-848. [CrossRef] [PubMed]

16. Zhao, Y.; Kang, L.P.; Liu, Y.X.; Liang, Y.G.; Tan, D.W.; Yu, Z.Y.; Cong, Y.W.; Ma, B.P. Steroidal saponins from the rhizome of Paris polyphylla and their cytotoxic activities. Planta Medica 2009, 75, 356-363. [CrossRef] [PubMed]

17. Agrawal, P.K.; Jain, D.C.; Pathak, A.K. NMR spectroscopy of steroidal sapogenins and steroidal saponins: An update. Magn. Reson. Chem. 1995, 33, 923-953. [CrossRef]

18. Agrawal, P.K.; Jain, D.C.; Gupta, R.K.; Thakur, R.S. Carbon-13 NMR spectroscopy of steroidal sapogenins and steroidal saponins. Phytochemistry 1985, 24, 2479-2496. [CrossRef] 
19. Xiao, C.M.; Huang, J.; Zhong, X.M.; Tan, X.Y.; Deng, P.C. Two New Homo-aro-cholestane Glycosides and a New Cholestane Glycoside from the Roots and Rhizomes of Paris polyphylla var. Pseudothibetica. Helv. Chim. Acta 2010, 92, 2587-2595. [CrossRef]

20. Agrawal, P.K. Assigning stereodiversity of the 27-Me group of furostane-type steroidal saponins via NMR chemical shifts. Steroids 2005, 70, 715-724. [CrossRef] [PubMed]

21. Zhang, J.; Ma, B.P.; Kang, L.P.; Yu, H.S.; Yang, Y.; Yan, X.Z. NMR studies of two furostanol saponins isolated from Polygonatum Kingianum. Chin. J. Magn. Reson. 2006, 23, 30-40.

22. Mahato, S.B.; Sahu, N.P.; Ganguly, A.N. Steroidal saponins from Dioscorea floribunda: Structures of floribundasaponins A and B. Phytochemistry 1981, 20, 1943-1946. [CrossRef]

23. Tian, X.; Feng, J.; Tang, H.; Zhao, M.; Li, Y.; Hai, W.; Zhang, X. New cytotoxic triterpenoid saponins from the whole plant of Clematis lasiandra Maxim. Fitoterapia 2013, 90, 233-239. [CrossRef] [PubMed]

24. Kasai, R.; Okihara, M.; Asakawa, J.; Mizutani, K.; Tanaka, O. ${ }^{13} \mathrm{C}$ NMR study of $\alpha$-anomeric and $\beta$-anomeric pairs of D-mannopyranosides and L-rhamnopyranosides. Tetrahedron 1979, 35, 1427-1432. [CrossRef]

25. Zhang, Y.; Yang, C.R.; Zhang, Y.J. Steroidal saponins from the rhizomes of Polygonatum prattii. J. Asian Nat. Prod. Res. 2016, 18, 268-273. [CrossRef] [PubMed]

26. Xie, B.B.; Liu, H.Y.; Ni, W.; Chen, C.X. Ypsilandrosides C-G, five new spirostanol saponins from Ypsilandra thibetica. Steroids 2009, 12, 950-955. [CrossRef] [PubMed]

27. Kang, L.P.; Huang, Y.Y.; Zhan, Z.L.; Liu, D.H.; Peng, H.S.; Nan, T.G.; Zhang, Y.; Hao, Q.X.; Tang, J.F.; Zhu, S.D.; et al. Structural characterization and discrimination of the Paris polyphylla var. yunnanensis and Paris vietnamensis based on metabolite profiling analysis. J. Pharm. Biomed. Anal. 2017, 142, 252-261. [CrossRef] [PubMed]

28. Tang, L.Y.; Wang, Z.J.; Wu, H.W.; Yokosuka, A.; Mimaki, Y. Steroidal glycosides from the underground parts of Dracaena thalioides and their cytotoxic activity. Phytochemistry 2014, 107, 102-110. [CrossRef] [PubMed]

29. Khodakov, G.V.; Akimov, Y.A.; Shashkov, A.S.; Kintia, P.K.; Grishkovets, V.I. Triterpene and steroid saponins isolated from two Melilotus species. Oxyg. Transp. Tissue XXXIII 1996, 405, 211-222.

30. Li, Y.H.; Liu, C.X.; Xiao, D.; Han, J.; Yue, Z.G.; Sun, Y.; Fan, L.; Zhang, F.; Meng, J.; Zhang, R.; et al. Trillium tschonoskii steroidal saponins suppress the growth of colorectal Cancer cells in vitro and in vivo. J. Ethnopharmacol. 2015, 168, 136-145. [CrossRef] [PubMed]

31. Lee, H.J.; Watanabe, B.; Nakayasu, M.; Onjo, M.; Sugimoto, Y.; Mizutani, M. Novel steroidal saponins from Dioscorea esculenta (Togedokoro). Biosci. Biotechnol. Biochem. 2017, 81, 2253-2260. [CrossRef] [PubMed]

32. Lu, Y.Y.; Luo, J.G.; Huang, X.F.; Kong, L.Y. Four new steroidal glycosides from Solanum torvum and their cytotoxic activities. Steroids 2009, 74, 95-101. [CrossRef] [PubMed]

33. Tian, X.R.; Tang, H.F.; Lin, H.W.; Cheng, G.; Wang, S.W.; Zhang, X. Saponins: The potential chemotherapeutic angents in pursuing new anti-glioblastoma drugs. Mini-Rev. Med. Chem. 2013, 13, 1709-1724. [CrossRef] [PubMed]

34. Fu, Q.; Zan, K.; Zhao, M.; Zhou, S.; Shi, S.; Jiang, Y.; Tu, P. Triterpene saponins from Clematis chinensis and their potential anti-inflammatory activity. J. Nat. Prod. 2010, 73, 1234-1239. [CrossRef] [PubMed]

35. Lin, H.; Zhang, X.; Cheng, G.; Tang, H.F.; Zhang, W.; Zhen, H.N.; Cheng, J.X.; Liu, B.L.; Cao, W.D.; Dong, W.P.; et al. Apoptosis induced by ardipusilloside III through BAD dephosphorylation and cleavage in human glioblastoma U251MG cells. Apoptosis 2008, 13, 247-257. [CrossRef] [PubMed]

36. Dang, Y.; Wu, W.; Xu, Y.; Mu, Y.; Xu, K.; Wu, H.; Zhu, Y.; Zhang, C. Effects of low-level laser irradiation on proliferation and functional protein expression in human RPE cells. Lasers Med. Sci. 2015, 9, 2295-2302. [CrossRef] [PubMed]

37. Wang, Z.Y.; Yang, J.; Xu, G.; Wang, W.; Liu, C.H.; Yang, H.H.; Yu, Z.B.; Lei, Q.Q.; Xiao, L.; Xiong, J.; et al. Targeting miR-381-NEFL axis sensitizes glioblastoma cells to temozolomide by regulating stemness factors and multidrug resistance factors. Oncotarget 2014, 6, 3147-3164. [CrossRef] [PubMed]

Sample Availability: Samples of the compounds 1-10 are available from the authors. 